\title{
Vanadium induced impairment of haem synthesis
}

\author{
C MISSENARD, ${ }^{1}$ G HANSEN ${ }^{2}$, D KUTTER, ${ }^{3}$ A KREMER ${ }^{3}$ \\ From the Laboratoire Clinique Eich, ${ }^{1}$ the Laboratoire National de Santé, ${ }^{2}$ and Centre Universitaire de \\ Luxembourg, ${ }^{3}$ Département des Sciences, Luxembourg
}

ABSTRACT Biochemical and haematological profiles of workers exposed to vanadium were
compared with those of non-exposed age matched subjects. A significantly positive and dose related-
correlation between serum vanadium and zinc protoporphyrin (ZPP) was observed. Normal leadw
concentrations excluded this heavy metal as a possible cause. Inhibition of the reduction of $\mathrm{Fe}^{+++}$too
$\mathrm{Fe}^{++}$by vanadium is discussed as the possible cause of interference of vanadium with haem synthesis.
Iron and iron binding capacity were found to be significantly lower and ferritin significantly higher in
the population exposed to vanadium. Strong inter-individual variations do not allow an explanation
of this interference with iron metabolism.

Inhalation of $\mathrm{V}_{2} \mathrm{O}_{5}$-dust is reported to be the most important source of vanadium intoxication. The main acute effects are conjunctival and respiratory.' Chronic intoxication is rarely reported and the exhaustive review of Wennig and Kirsch does not mention haematological effects. ${ }^{2}$

Erythrocyte zinc protoporphyrin (ZPP) is a valuable indicator of abnormal haem synthesis. ${ }^{34} \mathrm{In} \mathrm{Fe}^{++}$. deficiency the mitochondrial ferrochelatase of the erythroblasts incorporates $\mathrm{Zn}^{++}$instead of the missing $\mathrm{Fe}^{++}$into the protoporphyrin molecule. This also happens in lead intoxication, probably because the reduction of $\mathrm{Fe}^{+++}$is inhibited by lead. In the present paper we show that exposure to vanadium may also increase the synthesis of ZPP.

The exposed group consisted of workers engaged in extracting vanadium from slugs or in the melting of vanadium steel. The biochemical investigation included the determination of serum iron, iron binding capacity, ferritin, serum vanadium, and fluorimetry of ZPP to detect eventual interference with haem synthesis. The same estimations were performed on a nonexposed, age matched reference population drawn from workers of a hydroelectric power plant.

\section{Material and methods}

ZPP was determined by means of an AVIV 206 hematofluorimeter (Biomedical Inc, Lakewood NJ, USA) ${ }^{34}$ Routine biochemistry was performed with a Hitachi 704 and haematology on the Coulter 8-80 automatic equipment. A Boehringer Mannheim automatic ELISA processor ES 22 was used to determine ferritin. Serum iron and iron binding capacity were determined manually by the ferrozines method (J Seidel, unpublished data).

Serum vanadium concentration was determined on a Perkin-Elmer Zeemann 3030 atomic absorptior 100 spectrophotometer with the use of pyrolytically coated graphite tube and pulsed Zeemann backgroung correction. A hollow cathode vanadium lamp from Perkin-Elmer was used at a current of $40 \mathrm{~mA}$, a slit $\overrightarrow{0}$ $0.7 \mathrm{~nm}$, and an absorption wavelength at $318.4 \mathrm{~nm}$ All glass and plastic material was acid soaked (0.1 mo믈 $\mathrm{HCl} / \mathrm{l})$ and rinsed with distilled water before use $\overrightarrow{\vec{P}}$ Serum samples for vanadium determination were collected in trace element free glass containers from Becton-Dickinson (BD 60526) and were centrifuge and decanted into a second glass tube. Any contact with rubber stoppers was avoided. Samples were kepto frozen until analysed.

No certified serum reference material either from the National Bureau of Standards or from the Community Bureau of Reference was available fop vanadium determination. A standard addition method was used for calibration. The stock vanadiump solution prepared from BDH Chemicals Ltd, Poole? (UK), contained $19.6 \mathrm{mmol} / \mathrm{l}$ and the working solu tion $19.6 \mu \mathrm{mol} / 1$. The latter was prepared daily in twics distilled water and added to a pool of randoml collected serum. The addition of $5,10,15$, and $20 \mu \mathrm{l}$ of working standard to $1 \mathrm{ml}$ of pooled serum gave aw range of $0.1,0.2,0.3$, and $0.4 \mu \mathrm{mol} / 1\left(5.0,9.9,14.8{ }^{\circ}\right.$ and $19.6 \mu \mathrm{g} / \mathrm{l})$. Absorption was linear at least up to $\mu \mathrm{mol} / \mathrm{l}$.

All samples were diluted 1:1 with Triton X-10@ 
$(1 \mathrm{~g} / \mathrm{l})$ for better solubilisation. Graphite furnace conditions are described in table 1 . To avoid splashing, each specimen was introduced into the graphite tube in three portions of $30 \mu \mathrm{l}$ of diluted sample. They were dried at $500 / 1400^{\circ} \mathrm{C}$ after every addition (asterisk marked steps). Ash of the entire specimen was atomised at maximum furnace temperature with argon gas stop in the pyrolytically coated graphite tubes. Figure 1 shows an atomic absorption spectrum. No loss of vanadium could be detected at the charring temperature of $1400 / 1700^{\circ} \mathrm{C}$. The powerful Zeemann background correction overcomes a possible signal enhancement by organic matrix effects described by Stroop et $\mathrm{al}^{5}$ as shown by overlay plot and linearity of aqueous and biological matrix containing standard curves (fig 2). A detection limit of $0.04 \mu \mathrm{mol} / 1(2 \mu \mathrm{g} / \mathrm{l})$ is considered sufficient for the present investigation and allows relatively rapid and reliable analyses of a large number of samples.

Serum vanadium concentration determined in a normal, non-exposed population was found to be below $0.04 \mu \mathrm{mol} / 1(2 \mu \mathrm{g} / \mathrm{l})$. At a concentration of 0.3 $\mu \mathrm{mol} / 1(14.8 \mu \mathrm{g} / \mathrm{l})$ the interassay variation coefficient was below $5 \%$.

\section{Results}

\section{VANADIUM IN SERUM}

For the entire reference population vanadium concentrations were found at or below the detection limit of $2 \mu \mathrm{g} / \mathrm{l}$. This was also the case in five of the exposed workers. Measurable concentrations ranging between 3 and $37 \mu \mathrm{g} / \mathrm{l}$ were detected in the remaining 27 members of this group (fig 3 ). In this group the mean

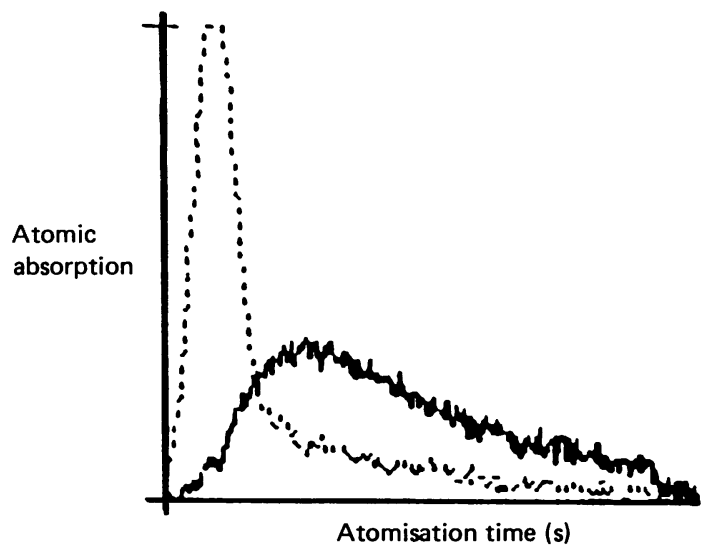

Fig 1 Atomic absorption spectrum for serum vanadium $2700^{\circ} \mathrm{C}$, slit $0.7 \mathrm{~mm}, 318.4 \mathrm{~nm}$. Pyrolytically coated graphite tubes. Vanadium absorption, unspecific absorption; Zeemann background correction spectrum.
Table 1 Graphite furnace conditions (Perkin-Elmer Zeemann 3030 atomic absorption spectrophotometer)

\begin{tabular}{|c|c|c|c|c|}
\hline \multirow[b]{2}{*}{ Steps } & \multirow{2}{*}{$\begin{array}{l}\text { Furnace } \\
\text { temperature } \\
\left({ }^{\circ} \mathrm{C}\right)\end{array}$} & \multicolumn{2}{|c|}{ Seconds } & \multirow{2}{*}{$\begin{array}{l}\text { Argon } / \mathrm{min} \\
\text { (ml) }\end{array}$} \\
\hline & & Ramp & Hold & \\
\hline $\begin{array}{l}\text { Drying* } \\
\text { Ashing* } \\
\text { Ashing* } \\
\text { Ashing* } \\
\text { Gas stop } \\
\text { Atomisation } \\
\text { Cleaning }\end{array}$ & $\begin{array}{r}130 \\
500 \\
1400 \\
1700 \\
1700 \\
2700 \\
2750\end{array}$ & $\begin{array}{r}40 \\
20 \\
15 \\
4 \\
1 \\
1 \\
1\end{array}$ & $\begin{array}{r}10 \\
5 \\
5 \\
4 \\
1 \\
6 \\
2\end{array}$ & $\begin{array}{r}300 \\
300 \\
300 \\
300 \\
0 \\
0 \\
300\end{array}$ \\
\hline
\end{tabular}

vanadium concentration was $9 \cdot 54 \mu \mathrm{g} / \mathrm{l}$. The difference between this value and the mean of the reference group is highly significant $(p<0.001)$.

ZPP

Values are shown in fig 4. Basic statistics of the reference group lie within the normal range of 1.5-2.7 $\mu \mathrm{g} \mathrm{ZPP} / \mathrm{g} \mathrm{Hb}$ determined in a previous study. ${ }^{4}$ There was, however, a slight overlap between the two populations; three members of the reference group showed slightly raised ZPP. The absence of any other abnormality indicated prelatent iron deficiency. Normal values were found in nine of the exposed workers, the remaining 23 showing raised values between 2.8 and $9.3 \mu \mathrm{g} \mathrm{ZPP} / \mathrm{g} \mathrm{Hb}$. The difference between the means of the two groups -2.2 and $3.9 \mu \mathrm{g}$ $\mathrm{ZPP} / \mathrm{g} \mathrm{Hb}$ - was highly significant $(\mathrm{p}<0.001)$.



Fig 2 Calibration by standard addition method in water (G) and in pooled normal serum (O). 


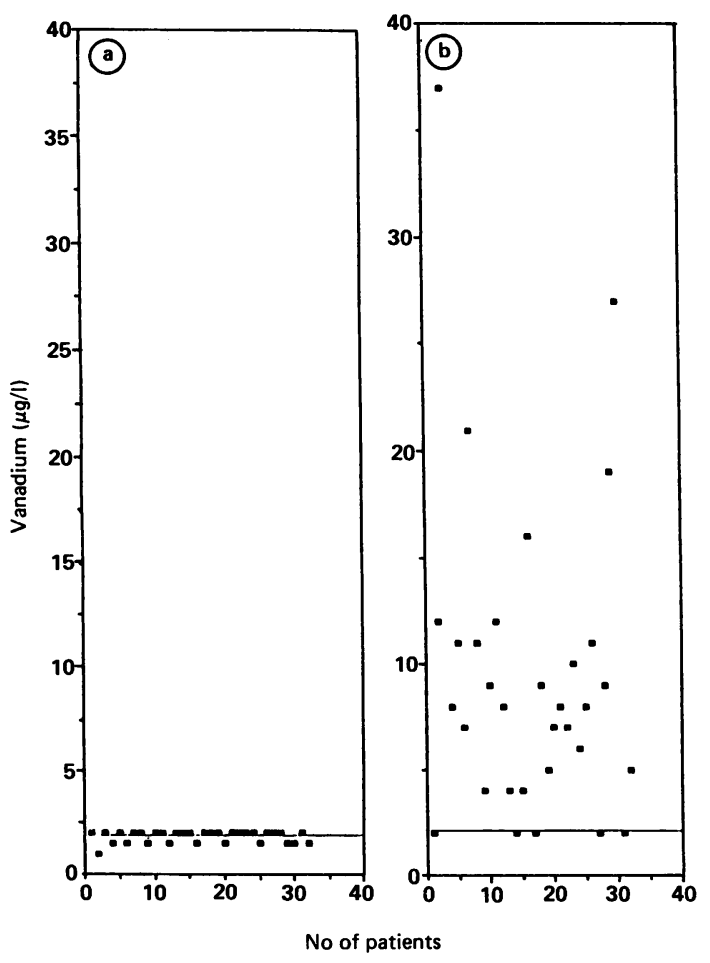

Fig 3 Vanadium in serum of unexposed (a) and exposed (b) workers.

CORRELATION BETWEEN VANADIUM AND ZPP Figure 5 shows linear correlation between the two parameters $(r=0.83)$. As parameters were not normally distributed, the Spearman rank correlation coefficient was also calculated and found to be $r_{3}=$ $0.848(\alpha=0.01)$.

\section{HAEMATOLOGY AND IRON METABOLISM}

There were no differences in the number of erythrocytes or in the concentration of haemoglobin. Table 2 shows that similarly there were no regular patterns of changes for iron, iron binding capacity, and ferritin between the exposed and the reference group or a significant correlation between these parameters and vanadium concentration. Nevertheless, the means of these three parameters differed significantly. Iron and iron binding capacity were significantly lower and ferritin significantly higher in the exposed population.

Erythrocyte sedimentation rate was performed for all participants. No pathological value was observed.

BLOOD LEAD CONCENTRATIONS

Blood lead concentrations were determined for all the members of the exposed group. Values were more or less normally distributed between 60 and $320 \mu \mathrm{g} / 1$, with a median value at $140 \mu \mathrm{g} / \mathrm{l}$. There was no correlation between lead concentration and the concentration oP. either ZPP or vanadium.

\section{Discussion}

Our data suggest that vanadium may interfere with? iron metabolism and haem synthesis. The absence of $\mathfrak{\wp}$ correlation between vanadium and iron, iron bindings capacity, and ferritin makes it impossible to associatethis interference with iron transport or iron stores:Modification of ferritin by chronic infection is rulect. out by the normal ESR.

Though transferrin binds vanadium, the binding of the V-ions by transferrin could not interfere 3 significantly with iron transport because the molaps concentration of transferrin is higher than the mola $\dot{5}$ concentration of vanadium. Thus the interference with iron metabolism remains unexplained.

Raised concentrations of vanadium correlate closely with the equally raised concentrations of ZPP. This clearly suggests that vanadium interferes with the

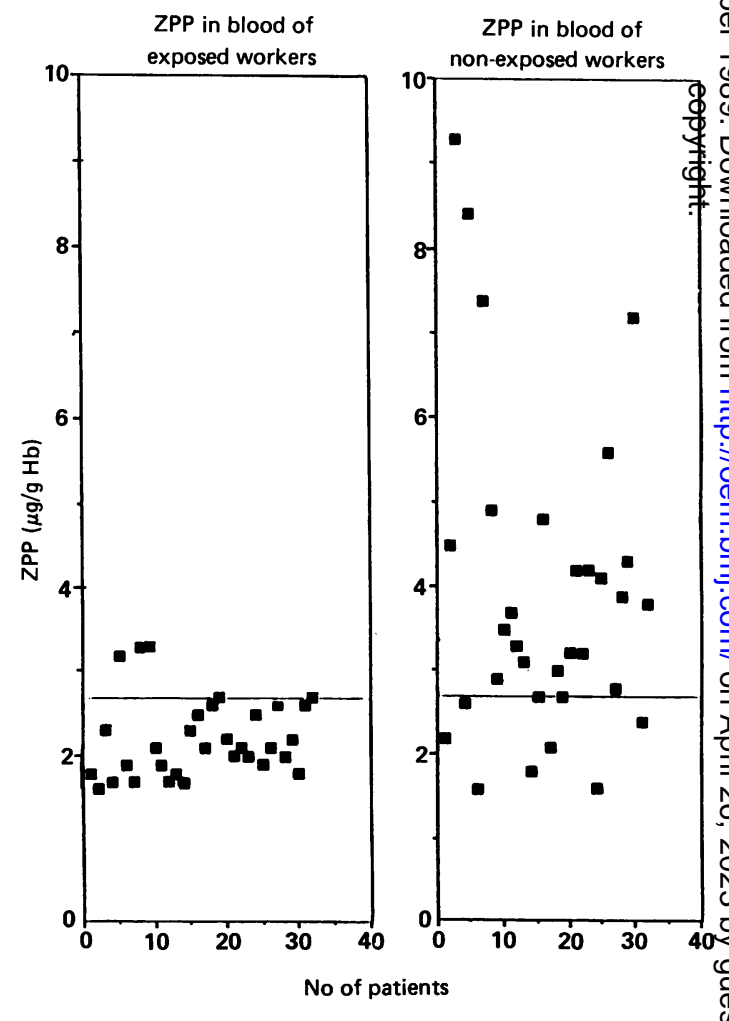

Fig 4 ZPP in blood of non-exposed and exposed workers. 
Table 2 Erythrocyte counts, haemoglobin, serum iron, iron binding capacity, and ferritin concentrations in 32 workers exposed to vanadium and a reference group of 32 non-exposed workers (mean $\pm S D$ )

\begin{tabular}{llllll}
\hline & $\begin{array}{l}\text { Erythrocytes } \\
\left(\times 10^{\circ} / \mu l\right)\end{array}$ & $\begin{array}{l}\text { Haemoglobin } \\
(\mathrm{g} / \mathrm{dl})\end{array}$ & $\begin{array}{l}\text { Serum iron } \\
(\mu \mathrm{g} / \mathrm{dl})\end{array}$ & $\begin{array}{l}\text { Iron binding capacity Ferritin } \\
(\mu \mathrm{g} / \mathrm{dl})\end{array}$ \\
\hline Exposed population & $4.85 \pm 0.38$ & $15.0 \pm 0.9$ & $104 \pm 37$ & $291 \pm 52$ & $215 \pm 119$ \\
Non-exposed population & $4.95 \pm 0.32$ & $15.2 \pm 0.8$ & $123 \pm 31$ & $330 \pm 46$ & $150 \pm 81$ \\
p & $<0.1(\mathrm{NS})$ & $<0.5(\mathrm{NS})$ & $<0.01^{*}$ & $<0.001^{* *}$ & $<0.001^{* *}$ \\
\hline
\end{tabular}

*p 0.05; ** 0.01 .

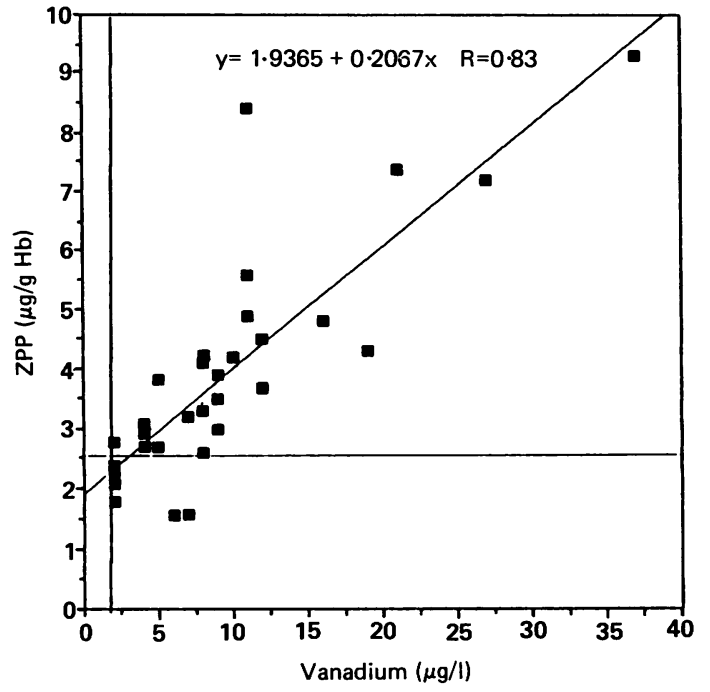

Fig 5 Correlation between vanadium and ZPP in 32 workers exposed to vanadium.

incorportation of $\mathrm{Fe}^{++}$-ions into the protoporphyrin molecule by ferrochelatase though this interference is unlikely through the inhibition of this enzyme by vanadium. The idea that similar inhibition by lead is responsible for the high ZPP concentration in lead intoxication had been rejected by Deybach who suggested that lead interferes with the reduction of $\mathrm{Fe}^{+++}$- the form of iron in transferrin and ferritinto $\mathrm{Fe}^{++}$necessary for incorporation into protopor- phyrin (JC Deybach, unpublished data). In other words lead creates $\mathrm{Fe}^{++}$-deficiency through the inhibition of ferroreductase. The question as to whether vanadium exerts a similar action on haem synthesis remains open.

\section{Conclusion}

We conclude that vanadium interferes with both iron metabolism and haem synthesis. Changes induced by exposure to vanadium in iron concentration, iron binding capacity, and ferritin are statistically significant but show strong interindividual variations. Inhibition of haem synthesis is documented by the rise of ZPP, which is more regular and seems clearly related to vanadium concentration. To our knowledge effects of this type have not yet been reported.

\section{References}

1 Moeschlin S. Klinik und Therapie des Vergiftungen. Stuttgart: Georg Thieme Verlag, 1965.

2 Wennig R, Kirsch N. Vanadium. In: Seiler HG, Sigel H, eds. Handbook on toxicity of inorganic compounds. New York: Marcel Dekker, 1984:749-65.

3 Lamola AA, Yamane T. Zinc protoporphyrin in the erythrocytes of patients with lead intoxication and iron deficiency anemia. Science 1974;186:936-8.

4 Kutter D, Al Haidari K, Missenard C. Valeur diagnostique d'un nouveau paramètre hématologique: la zinc-protoporphyrine. Bull Soc Sci Med Grand Duché Luxemb 1987;124:45-56.

5 Stroop SD, Helinek G, Greene HL. More sensitive flameless atomic absorption analysis of vanadium in tissue and serum. Clin Chem 1982;28:79. 